1 I.I. Schmalhausen Institute of Zoology, National Academy of Sciences of Ukraine, Kyiv, Ukraine e-mail: martynova_kv@ukr.net ORCID: http://orcid.org/0000-0002-9896-3504

2 National Museum of Natural History, National Academy of Sciences of Ukraine, Kyiv, Ukraine e-mail: martynov_av@ukr.net ORCID: http://orcid.org/0000-0002-6506-5134

\title{
NEW RECORDS \\ OF CERCERIS TUBERCULATA (VILLERS, 1787) (HYMENOPTERA: CRABRONIDAE) FROM UKRAINE, WITH NOTES ON ITS PARASITOIDS AND PREY
}

Present paper reports observations on the digger wasp Cerceris tuberculata (Villers, 1787) (Hymenoptera: Crabronidae), listed in Red Data Book of Ukraine, its parasitoids and prey. The observations revealed two parasitoids associated with this wasp: a cuckoo wasp Hedychrum virens Dahlbom, 1845 (Chrysididae) and velvet ant Nemka viduata viduata (Pallas, 1773) (Mutillidae). The host-parasitoid association of this velvet ant and C. tuberculata is provided for the first time. Four species of weevils were registered as a prey of $C$. tuberculata, three of them are given for the first time herein. New records of the species from Zaporizhzhya and Kherson Regions are provided; the species is reported from Zaporizhzhia Region for the first time.

Keywords: Red Data Book of Ukraine, nest aggregation, parasitoid, prey, new records, steppe zone

\section{Introduction}

Cerceris tuberculata (Villers, 1787) (Hymenoptera: Crabronidae) is the largest representative of the genus in Europe (17-22 mm long). This species is protected by the Red Data Book of Ukraine (Akimov, 2009). It inhabits steppe biotops mainly, but can be also found at desert regions within the areal of its distribution (Kazenas, 2002).

Цитування: Martynova K.V., Martynov A.V. New Records of Cerceris tuberculata (Villers, 1787) (Hymenoptera: Crabronidae) from Ukraine, with Notes on its Parasitoids and Prey. Ukrainian Entomological Journal. 2021. № 1-2 (19). C. 77-84. https://doi.org/10.15421/282105 
There are four described subspecies of Cerceris tuberculata: nominative subspecies distributed within Southern Europe, Mediterranean and Iran, ssp. evecta Shestakov, 1922 known from China and Mongolia, ssp. cypria Beaumont, 1958 described from Cyprus and ssp. ogotai Tsuneki, 1971 distributed in Mongolia (Bohart and Menke, 1976; Kazenas, 2002; Rosa and Soon, 2013).

Cerceris tuberculata is known to nest in vertical walls of slopes and drains, preferring clay and sandy or clay grounds (Kazenas, 2002; Semik and Semik, 2002); its nest aggregations can be rather dense, up to 80 nest burrows for $1 \mathrm{~m}^{2}$ (for details of nest structure see Semik and Semik, 2002).

Large weevils of the subfamily Lixinae (Curculionidae) were reported as the prey of this crabronid wasp. Old records generally refer to the representatives of the genus Cleonis Dejean, 1821 (previously gives as Cleonus Schönherr, 1826) (Bischoff, 1927; Grandi, 1959, 1961). Fabre (1914) mentioned tree species as a prey of C. tuberculata: Leucophyes pedestris (Poda, 1761) (as Cleonus ophthalmicus (Rossi, 1790)), Mecaspis alternans (Herbst, 1795) (as Cleonus alternans Herbst, 1795) and Cleonis albidus Schoenherr, 1826 (as Cleonus albidus); notably that two last species were recorded based only on one specimen each. But, Semik and Semik (2002) specified the prey range of $C$. tuberculata by listing three weevil species, namely Lixus algirus (Linnaeus, 1758), Larinus latus (Herbst, 1783) and Leucomigus candidatus (Pallas, 1771). Furthermore Agnoli and Rosa (2021) added the one more species, Larinus onopordi (Fabricius, 1787).

It is noteworthy that the stem borer, Lixus algirus is the major insect pest of faba bean in the Mediterranean region (Taadaouit et al., 2021), Larinus latus is an agent of biological pest control against Onopordum thistles in Australia (Pettit and Briese, 2000), while Leucomigus candidatus is protected by the Red Data Book of Ukraine (Akimov, 2009).

Cerceris tuberculata was previously reported from Eastern and Southern regions of Ukraine, namely Sumy, Kharkiv, Luhansk, Odessa, Mykolaiv, Kherson Regions and Crimea (see Protsenko and Gorobchishin, 2015; Stepoviy, 2017; Kavurka et al., 2019; Kletonkin, 2019 for known localities and map). Present contribution reports C. tuberculata from Zaporizhzhia Region for the first time.

No data on the parasitoids reared from the nests of $C$. tuberculata have never been published.

Nevertheless, Agnoli and Rosa (2021) observed the activity of Hedychrum virens Dahlbom, 1845 (Chrysididae) within the nest site of C. tuberculata at Karadag Nature Reserve, Crimea, Ukraine. Present contribution confirms the fact of host-parasitoid relations between these wasps. There are no other host records for this cuckoo wasp.

Hedychrum virens is a large cuckoo wasp (if compared to other species of the family known from Ukraine) and the biggest elampine chrysidid in Europe (Agnoli and Rosa, 2021). The species is locally distributed within the warm regions of Mediterranian (Linsenmaier, 1959, 1968; Rosa and Soon, 2013).

The case of parasitoidism of the velvet ant Nemka viduata viduata (Pallas, 1773) (Mutillidae) on C. tuberculata has not been reported previously. The 
New Records of Cerceris tuberculata (Villers, 1787) (Hymenoptera: Crabronidae) from Ukraine

list of confirmed hosts for this parasitoid comprised digger wasps Bembecinus tridens (Fabricius, 1781), Stizus continuus (Klug, 1835), and Bembix bidentata Vander Linden 1829 (Hymenoptera: Crabronidae: Bembecinae) (Grandi, 1961; Tormos et al., 2003; Tormos, 2009).

Nemka viduata viduata is an West Palaearctic taxon (in chorological pattern), rather common in sandy coastal areas (Palmerini, 2013). It was previously reported for Ukraine as a whole (Lelej and Yildirim, 2009), and for its separate regions, including Mykolaiv and Kharkiv Regions (Stepoviy, 2017).

\section{Materials and methods}

Observations have been performed in natural habitat of C. tuberculata on June 22 and 26,2019. The studied area covered a $30 \mathrm{~m}$ long section of the sand and clay road passing through the halophyte steppe on bank of Malyi Utluk River in vicinity of Shelyuhy village, N46.546134 E035.199960 (Zaporizhzhya Region, Ukraine). The observations had been carried out from 11.00AM to 5.00 PM each day. Visual observations had been mainly performed. We also made the notes on behavior of studied crabronid wasp and its natural enemies. Several specimens of revealed parasitoids were fixed with $96 \%$ ethanol for further study and identification (four exemplars for each species). The specimens of $C$. tuberculata had only been observed visually, because this is a rare insect species protected by the Red Book of Ukraine (Akimov, 2009). We also collected two paralyzed specimens of weevil L. candidatus than were carried and then thrown away by the crabronid wasp; no living specimens of this protected species were collected. Photos of specimens and habitats were taken with Canon SX30IS.

Additionally, C. tuberculata was recorded in several other places within Kherson and Zaporizhzhya Regions, but nesting sites were not found and observations on the behavior have not been performed. This additional visual records are labeled as follows: one imago (female), Ukraine, Kherson Region, Chaplynka district, vicinity of Novovolodymyrivka village, steppe area along Syvash Gulf, 46.24005 33.81210, Martynov A.V. leg., 10-16.07.2020; 7 imagoes on flowers of Asteraceae, Ukraine, Zaporizhzhya Region, vicinity of Lymans'ke village, steppe area on bank of Molochnyi Estuary, 46.42770 035.34116, Martynov A.V. et Martynova K.V. leg., 20-25.08.2019; one imago (female), Ukraine, Zaporizhzhya Region, vicinity of Shelyuhy village, forest belt near field and fallow, 46.54832 035.18648, Martynov A.V. leg., 17.06.2019.

Part of the records of the species mentioned in the contribution was uploaded as dataset on biodiversity on GBIF (Martynov \& Putchkov 2021).

\section{Results}

The observations revealed two parasitoids associated with C. tuberculata: a cuckoo wasp Hedychrum virens and velvet ant Nemka viduata viduata. We also registered a weevil Leucomigus candidatus (Curculionidae) protected by 
the Red Data Book of Ukraine (Akimov, 2009) as the one of prey items of this crabronid wasp at the studied habitat. Other three weevil species, Asproparthenis carinata (Zoubkoff, 1829), Coniocleonus nigrosuturatus, (Goeze, 1777) and Cleonis nigra (Scopoli, 1763), are registered as the prey of C. tuberculata for the first time.

Thus, the host-parasitoid association with cuckoo wasp H. virens is herein confirmed based on ethological observations. The activity of velvet ant $N$. viduata within the nest site of $C$. tuberculata also suggests the existence of host-parasitoid relations between these wasps.

Host Cerceris tuberculata (Villers, 1787) (Hymenoptera: Crabronidae). We could observe the large nests aggregation of C. tuberculata: more than 80 nest entrances were registered at sandy and clay road (Fig. 1A, B.). The nests were unevenly located, with groups situated at the open middle part of the road, at the road boundary and among the vegetation surrounding the road (Fig. 1C, D). The nest aggregation was generally sparse, the distance between nests varied considerably, but exceeded $30 \mathrm{~cm}$ in most of cases. The nest entrances had approximately $15 \mathrm{~mm}$ in diameter.

Numerous females of $C$. tuberculata were observed demonstrating similar acts of behavior: (i) staying in the nest burrow with head facing the entrance; (ii) flying away for hunting to neighboring steppe areas; (iii) carrying the 'preparalized' weevils to the nest entrance; (iv) paralyzing the specimens of weevils by injecting venom to the thorax ventrally (Fig. 1F); (v) dragging the paralyzed prey into the nest.

Four species of weevils were used as a prey by C. tuberculata within the observed habitat: Asproparthenis carinata, Coniocleonus nigrosuturatus, Cleonis nigra and Leucomigus candidatus. Most common as prey was weevil Asproparthenis carinata that develops on plants of the subfamily Chenopodioideae. The representatives of this subfamily were numerous within surrounding halophyte steppe. Obviously, C. tuberculata is hunting mainly near the nests.

It is noteworthy, that females of $C$. tuberculata used to hold and drag the weevils by grasping their rostrum with mandibles and leaning against the large protuberance on clypeus (Fig. 1E, F).

We had also registered several males of $C$. tuberculata at the nest site. They were flying above the surrounding vegetation and sporadically landed on flowering plants or soil. The males avoided to attend the nests.

Parasitoid Hedychrum virens Dahlbom, 1845 (Hymenoptera: Chrysididae). We had registered numerous females of $H$. virens at the study area with the aggregation of host nests. Parasitoids had been flying from one nest entrance to another one, tending to reveal the temporary abandoned nest burrow (while female of $C$. tuberculata gone hunting for prey). Females of $H$. virens preferred to stay close to the nest even if the host wasp had been entering it, or staying inside, or carrying the prey inside. In several cases we could see that C. tuberculata females noticed the parasitoid and demonstrated the "busy" movements, but they always chose to handle with prey item than to drive away the females of $H$. virens. 

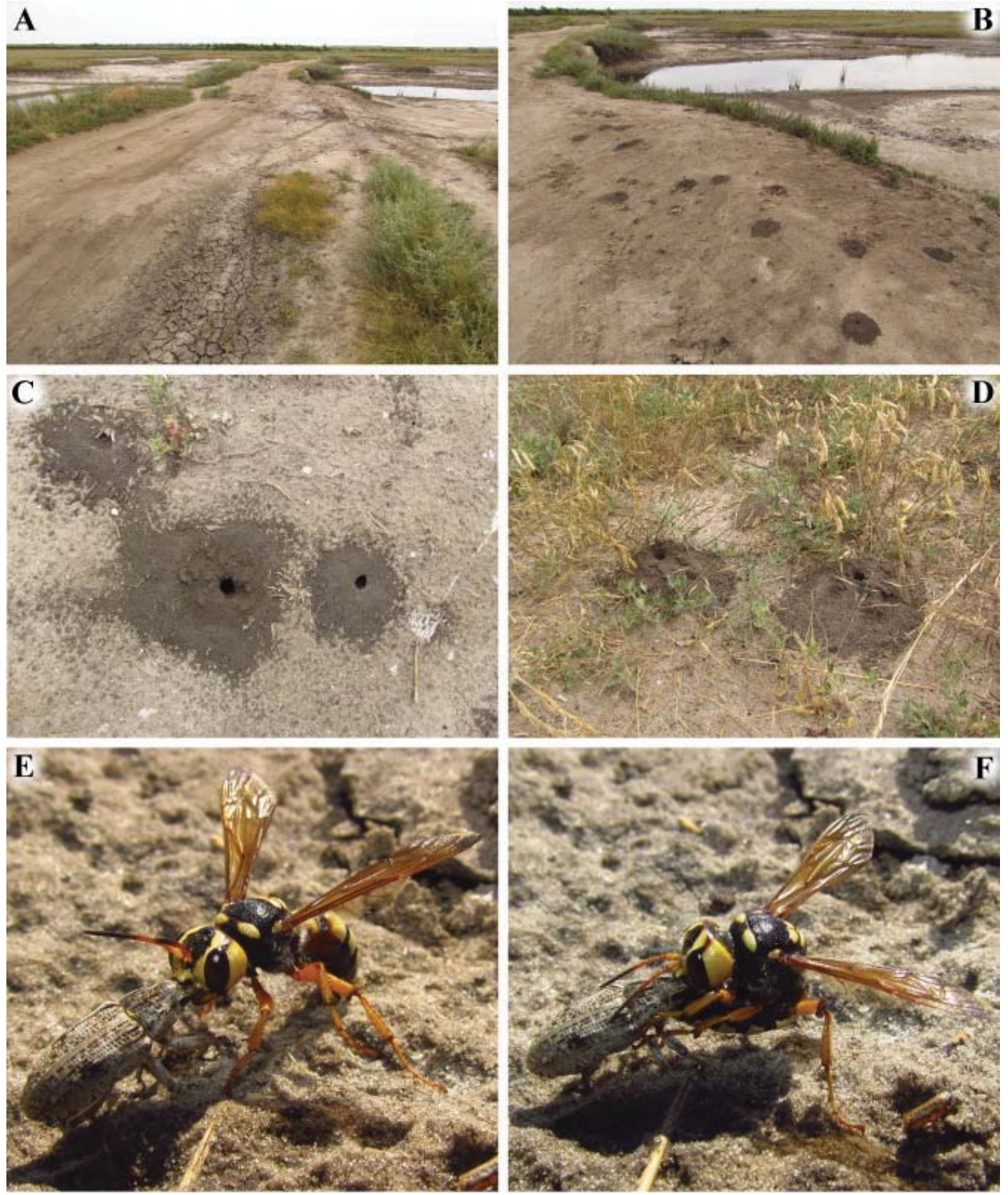

Fig. 1. Cerceris tuberculata (Villers, 1787), its habitat and behavior: $A-$ total view of habitat; $B$ - aggregation of nests; $C$ - nests at open area; $D$ - nests among vegetation; $E$ - female holding the weevil before paralyzing; $F$ - female paralyzing the weevil

The adults of this cuckoo wasp were active during all time of observations. They could be easily noticed because of the large body size (ca. 13-15 mm long) and frequent short flights with numerous landings among the nest entrances.

No males of $H$. virens had been found within the study site during the days of research. The sexual dimorphism of this parasitoid wasp is expressed in the body coloration (and features of morphology): females have green-blue and red parts of the thorax vs males with thorax entirely green-blue. Therefore, the 
sexes of $H$. virens could be easily differed even during the field observations, especially considering their large body size.

Parasitoid Nemka viduata viduata (Pallas, 1773) (Hymenoptera: Mutillidae). Numerous specimens of the velvet ant $N$. viduata viduata were also recorded among the nests of crabronid wasp C. tuberculata. In contrast to cuckoo wasp discusses above, both sexes of the velvet ant were active within the study area. Wingless females have been 'running' among the nest burrows of the host wasp, while winged males preferred to visit flowering plants and only rarely landed at the boundary of the road containing the nest aggregation. The features of behavior that we could observe for $N$. viduata viduata corresponded to the data minutely described by Palmerini (2013).

The females of the velvet ant were almost as numerous as the specimens of cuckoo wasp $H$. virens, but they moved much more slowly and their activity was shifted to the end of the day.

\section{Acknowledgements}

This research was supported by the National Research Foundation of Ukraine grants for KVM (grant registration number 2020.02/0369) and AVM (grant registration number 2020.02/0276). The authors grateful to Vitaliy Yu. Nazarenko (Schmalhausen Institute of Zoology, National Academy of Sciences of Ukraine) for the help with determination of weevils.

\section{REFERENCES}

Agnoli, G.L. and Rosa, P., 2021. Hedychrum virens and Cerceris tuberculata. [online] Chrysis.net website. Available at: https://www.chrysis.net/chrysididae/hedychrum-virens. [Accessed 1 October 2021].

Ait Taadaouit, N., El Fakhouri, K., Sabraoui, A., Rohi, L., and El Bouhssini, M., 2021. Lixus algirus L. (Coleoptera: Curculionidae): biology, population fluctuation, infestation as affected by varieties, location, and planting dates in Morocco. Journal of Entomological and Acarological Research, 53 (1). https://doi.org/10.4081/jear.2021.9324

Akimov, I.A., ed., 2009 Red Data Book of Ukraine Animals. Kyiv: Globalconsulting (in Ukrainian: Акімов, I.A., ред. Червона книга України. Тваринний світ).

Bischoff, H., 1927. Biologie der Hymenopteren. Eine Naturgeschichte der Hautflügler. Biologische Studienbücher. 5. Berlin.

Bohart, R.M. and Menke, A.S., 1976. Sphecid Wasps of the World: A Generic Revision. Berkeley: California University Press.

Fabre, J.H., 1914. Souvenirs Entomologiques (Première Série). 7. Delagrave, Paris.

Grandi, G., 1959. Contributi alla conoscenza degli Imenotteri Aculeati. XXVIII. Bollettino dell'Istituto di Entomologia di Bologna, 23: 239- 292.

Grandi, G., 1961. Studi di un entomologo sugli imenotteri superiori. Bollettino dell'Istituto di Entomologia di Bologna, 25: 1- 659.

Kavurka, V.V., Zaika, M.I., Popov, G.V. and Lazarev, I.E., 2019. New findings of Arachnida, Myriapoda and Insecta, listed in the Red Data Book of Ukraine. Report 2. Materials to the 4th edition of the Red Data Book of Ukraine. Animals. Series: "Conservation Biology in Ukraine", 7(3): 134- 141 (in Ukrainian: Кавурка В.В., Заїка М.I., Попов Г.В., 
Нові знахідки павукоподібних (Arachnida), багатоніжок (Myriapoda) та комах (Insecta), які занесені до Червоної книги України. Повідомлення 2).

Kazenas V.L., 2002. Digger wasps (Hymenoptera, Sphecidae) of Kazakhstan. Tethys Entomological Research, 4: 1- 176 (in Russian: Казенас, В.Л. Роющие осы (Hymenoptera, Sphecidae) Казахстана).

Kletonkin, V.G., 2019. Records of animals included to Red Data Book of Ukraine within Dvorichanskyi district of Kharkiv Region. Materials to the 4th edition of the Red Data Book of Ukraine. Animals. Series: "Conservation Biology in Ukraine”, 7(3): 143- 145 (in Ukrainian: Клетьонкін В.Г. Знахідки тварин Червоної книги України у Дворічанському районі Харківської області).

Lelej, A.S. and Yildirim, E., 2009. A review of the Mutillidae (Hymenoptera) of Turkey. Zootaxa, 2160: 1-28. https://doi.org/10.11646/zootaxa.2160.1.1.

Linsenmaier, W., 1959. Revision der Familie Chrysididae (Hymenoptera) mit besonderer Berücksichtigungder europäischen Spezies. Mitteilungen der Schweizerischen Entomologischen Gesellschaft, 32: 1- 232.

Linsenmaier, W., 1968. Revision der Familie Chrysididae. Zweiter Nachtrag. Mitteilungen der Schweizerischen Entomologischen Gesellschaft, 41: 1- 144.

Martynov, A. and Putchkov, A., 2021. Records of herpetobiotic and other insects within steppe area of Ukraine. Part 1. Kherson and Zaporizhzhia Regions, 2019- 2021. Version 1.1. Ukrainian Nature Conservation Group (NGO). Occurrence dataset https://doi.org/10.15468/s9m854 [Accessed via GBIF.org on 2021-10-12].

Palmerini, M.M., 2013. Remarks on the behaviour of the Velvet Ant Nemka viduata viduata (Pallas, 1773) (Insecta Hymenoptera Mutillidae). Quaderno di Studi e Notizie di Storia Naturale della Romagna, 37: 237- 260.

Pettit, W.J. and Briese, D.T., 2000. The Demographic Performance of the Capitulum Weevil, Larinus latus, on Onopordum Thistles in its Native and Introduced Ranges. Proceedings of the X International Symposium on Biological Control of Weeds 4- 14 July 1999, Montana State University, Bozeman, Montana, USA: 739- 745.

Prozenko, Yu.V. and Gorobchishin, V.A., 2015. Digger wasps (Hymenoptera: Sphecidae, Crabronidae) from Red Book of Ukraine. The Kharkov Entomological Society Gazette, 23 (2): 20- 28 (In Russian: Проценко, Ю.В. и Горобчишин, В.А. Роющие осы (Hymenoptera: Sphecidae, Crabronidae), занеснные в Красную книгу Украины).

Rosa, P. and Soon, V., 2013. Fauna Europaea: Chrysididae. In: M.D. Mitroiu, ed. Fauna Europaea: Hymenoptera. Fauna Europaea Version 2.6. Available at: http://www.faunaeu.org [Accessed 1 October 2021].

Semik, E.A. and Semik, A.M., 2002. About prey and nesting site of Cerceric tuberculata (Villers, 1789) (Hymenoptera: Sphecidae). The Kharkov Entomological Society Gazette, 10 (1-2): 134 (In Russian: Семик, Е.A. и Семик, А.M., О добыче и гнездовом участке у Cerceric tuberculata (Villers, 1789) (Hymenoptera: Sphecidae)).

Stepoviy, R. (Efarilis), 2017. Cerceris tuberculata. Image ID \# 43875, 43247, 43237, 42028 In: UkrBIN: Ukrainian Biodiversity Information Network [public project \& web application]. UkrBIN, Database on Biodiversity Information. Available at: http://www. ukrbin.com [Accessed: 25 October 2021.

Tormos, J., 2009. Description of the mature larva of the sand wasp Bembix bidentata and its parasitoids (Hymenoptera: Crabronidae, Chrysididae, Mutillidae). Florida Entomologist, 92 (1): $43-53$.

Tormos, J., Asís, J.D. and Gayubo, S.F., 2003. Description of the mature larva of Nemka viduata (Pallas) (Hymenoptera: Mutillidae: Mutillinae), a parasitoid of Stizus continuus (Klug) (Hymenoptera: Crabronidae: Bembicinae). Journal of Entomological Science, 38 (4): $502-510$. 
К.В. Мартинова, О.В. Мартинов

\section{HOBI ЗНАХІДКИ CERCERIS TUBERCULATA (VILLERS, 1787) (HYMENOPTERA: CRABRONIDAE) У MEЖAХ УКРАЇ̈И, IЗ ДАНИМИ ЩОДО ПАРАЗИТОЇДІВ ТА ЗДОБИЧІ}

В цій роботі наведено дані спостережень за осою Cerceris tuberculata (Villers, 1787) (Hymenoptera: Crabronidae), що внесено до Червоної книги України, його паразитоїдами та здобиччю. В результаті досліджень виявлено два види паразитоїдів, що асоційовані із Cerceris tuberculata: оса-блискітка Hedychrum virens Dahlbom, 1845 (Chrysididae) та оса-німка Nemka viduata viduata (Pallas, 1773) (Mutillidae). Хазяїнопаразитний зв'язок між даною мутилідою та C. tuberculata нами виявлено вперше. У якості здобичі церцеріса горбкуватого нами відмічено чотири види довгоносиків, три з яких - вперше. Наведено нові реєстрації C. tuberculata з території Запорізької та Херсонської областей; для Запорізької області вид наведено вперше.

Ключові слов а: Червона книга України, агрегація гнізд, паразитоїд, здобич, нові знахідки, степова зона. 